\title{
Neurogenic Locus Notch Homolog Protein
}

3

National Cancer Institute

\section{Source}

National Cancer Institute. Neurogenic Locus Notch Homolog Protein 3. NCI Thesaurus.

Code C106438.

Neurogenic locus notch homolog protein 3 (2321 aa, $244 \mathrm{kDa}$ ) is encoded by the

human NOT CH3 gene. This protein plays a role in both cell fate commitment and cell-cell signaling. 